Chirurgia (2021) 116: S59-S64

No. 5 Supplement, December

Copyright@ Celsius

http://dx.doi.org/10.21614/chirurgia.116.5 Suppl.S59

\title{
Ductal Carcinoma In Situ: Pathology
}

\author{
Fabienne Sophie Wehweck* \\ Institute of Pathology, Faculty of Medicine, Ludwig Maximilian University, Munich, Germany
}

*Corresponding author:

Fabienne Sophie Wehweck, MD

Institute of Pathology

Faculty of Medicine

Ludwig Maximilian University, Munich

Germany

E-Mail: Fabienne.Wehweck@med.uni-muenchen.de

\section{Rezumat}

Carcinomul ductal in situ reprezintă un grup heterogen, din punct de vedere biologic şi morfologic, de neoplazii intraductale proliferative ale țesutului mamar şi de asemenea, o leziune precursoare importantă a dezvoltării carcinomului mamar invaziv, având o rată crescută de diagnosticare, datorită îmbunătățirii metodelor imagistice de diagnostic. $\mathrm{Cu}$ toate acestea, clasificarea exactă şi diferențierea de alte leziuni ale țesutului mamar poate reprezenta o provocare pentru medicul anatomopatolog. Prin urmare, articolul de față evidențiază atât aspectul clinic, cât şi macroscopic, dar şi clasificarea bazată pe histomorfologie şi imunohistochimie, pe lângă cele mai importante diagnostice diferențiale şi tipuri speciale de carcinom ductal in situ.

Cuvinte cheie: carcinom ductal in situ, patologie
Received: 20.10 .2021 Accepted: 28.11 .2021

\section{Abstract}

Ductal carcinomata in situ (DCIS) are both biologically and morphologically a heterogeneous group of neoplastic intraductal proliferations of the breast tissue, they represent an important precursor lesion for the development of invasive breast carcinoma and their diagnosis increases due to improved imaging. Nevertheless, the exact classification and differentiation from other lesions of the mammary gland tissue is often challenging for the pathologist. Therefore, this article highlights both the clinical and macroscopic presentation as well as the classification based on histomorphology and immunohistochemistry in addition to the most important differential diagnoses and the special types of DCIS. 
Key words: ductal carcinoma in situ, pathology

\section{Introduction}

Ductal carcinomata in situ (DCIS) are genetically and pathomorphologically a hetero-geneous group of neoplastic intraductal proliferations of the breast tissue. They are considered non-obligate precancerous lesions of invasive breast carcinomas.

\section{Material and Methods}

A summary of established knowledge and new findings on DCIS.

\section{Results}

\section{Clinical Presentation}

Today most DCIS are detected via mammography by it's association with microcalcifications in more than $70 \%$. These DCIS normally do not present as a palpable mass.

Mammography often underestimates the histologically determined extent in DCIS in approximately 30\% (1), because microcalcification can be irregularly distributed. DCIS tend to grow along ducts and in clusters with spaces sometimes more than $10 \mathrm{~mm}$ between them (2).

\section{Prognosis}

In untreated DCIS, the risk of subsequent invasive carcinoma is about $50 \%(3,4)$. Carcinomas usually develop within 10 years $(4,5)$, are usually of the non special type and are located in the same quadrant. Patients with DCIS can develope another DCIS or invasive carcinoma in the contralateral breast in $22 \%$ (6).

The higher the nuclear grade the higher the recurrence rate and the risk of progression to invasive carcinoma. The same goes for size (especially more than $2.5 \mathrm{~cm}$ ) and an incomplete removal (7). Lymph node metastases are found in $1-4.5 \%$ and are due to undetected (microinvasive) carcinomas due to "sampling errors". Therefore critical cases especially with high grade DCIS require extensive sampling and use of immunohistochemistry regarding myoepithelial markers (8).

\section{Etiology}

Etiological risk factors for DCIS are the same as for invasive breast cancer (9) for example nulliparity, late menopause or late age at first childbirth.

\section{Macroscopic Appearance}

DCIS rarely presents as a palpaple or visible mass. Sometimes you can see pale fibrotic areas with yellowish material in duct structures resembling comedo-type necrosis (Fig. 1).

Figure 1. Macroscopic appearance of a later histologically confirmed high grade DCIS (author's archive)

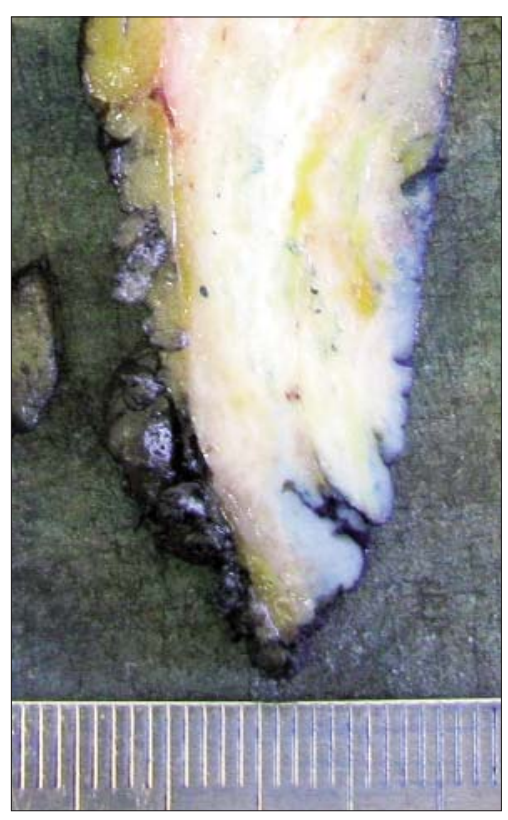




\section{Histopathology}

Histologically DCIS are a heterogeneous group.

Classically DCIS is defined as an intraductal proliferation of neoplastic epithelial cells with atypia. DCIS shows a preserved myoepithelial layer (Fig. 2) and is restricted to the ductulolobular unit. The proliferates may show a variety of nuclear grades and growth patterns or architecture.

The architecture may be papillary, micropapillary or solid. Focal or extensive comedonecrosis may occur. Those are eosinophilic material consiting of cellular and nuclear debris within the duct lumen.

DCIS may involve the adjacent lobules, so called lobular involvement (Fig. 3).

\section{Grading}

For grading DCIS is characterized by nuclear grade (low, intermediate, high), presence or absence of comedo-necrosis and architecture, while emphasizing the nuclear grade $(10,11)$. For nuclear grading, in addition to nucleus shape and nucleoli, the size of the nuclei must be taken into account (40x objective) (Table 1, 2).

\section{Pathological Report}

The WHO classification recommends documentation of the following parameters in a pathological report:

- grading;

- presence of necrosis;

- architecture;

- size [extent, distribution (continuous/ discontinuous) pattern];

- resection margins (if positive: focal or wide; if negative: distance from resection margins in $\mathrm{mm}$ ).

- presence or absence of: microcalcifications, wire probe, clips (for correlation with radiology report).

In the eighth edition oft he UICC TNM classification DCIS is staged „pTis (DCIS)“ (12).

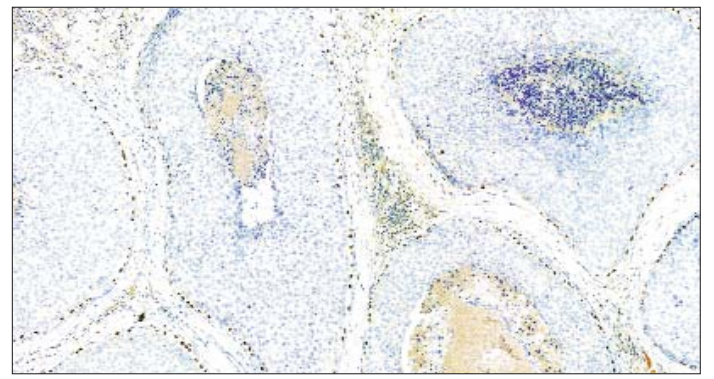

Figure 2. Preserved myoepithelium layer in DCIS high grade (p63, 10x) (author's archive)

\section{Biomarkers}

Determination of hormone receptors [estrogen and progesterone receptor (Fig. 8, 9)] in DCIS can be useful, but there is no international agreement or guideline. The evaluation is analogous to that of invasive breast carcinoma.

Her2 neu overexpression occurs especially in high grade DCIS (Fig. 10) and may differ from the expression in an accompanying invasive component (13).

DCIS as a precursor lesion of invasive breast cancer shows similar genomic alterations as invasive breast carcinomas, especially high grade DCIS (14). However, to date, there is no reliable molecular marker that indicates progression of DCIS to invasive carcinoma (15).

\section{Special types}

\section{Papillary DCIS}

Papillary DCIS consists of fine finger like

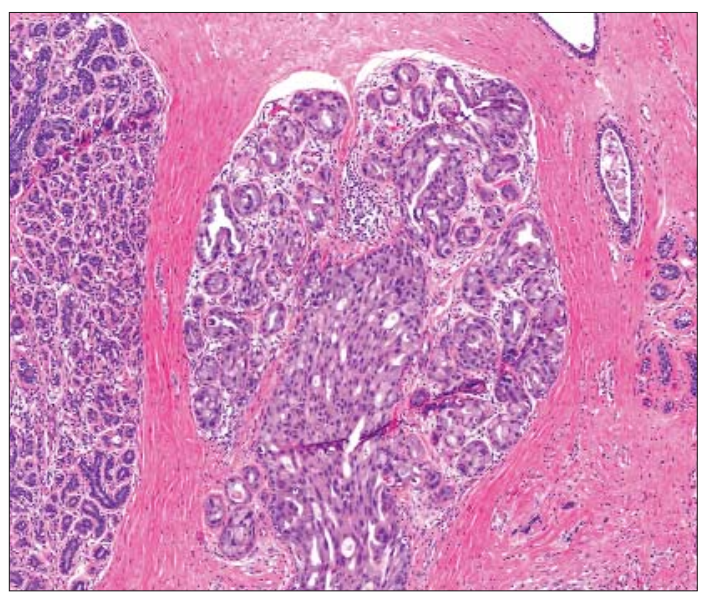

Figure 3. High grade DCIS with involvement of adjacent lobules (HE, $10 \mathrm{x}$ ) (author's archive) 
Table 1. Grading

\begin{tabular}{|c|c|c|c|c|}
\hline & nuclear grade & necrosis & calcification & architecture \\
\hline Low grade & small, monomorphic & extremely rare & lamellar & $\begin{array}{l}\text { mainly cribriform } \\
\text { or micropapillary }\end{array}$ \\
\hline Intermediate grade & moderate variability & maybe & $\begin{array}{l}\text { lamellar or } \\
\text { amorphous }\end{array}$ & variable \\
\hline High grade & $\begin{array}{l}\text { large, pleomorphic, } \\
\text { irregular contours }\end{array}$ & often comedo-type & amorphous & mainly solid \\
\hline
\end{tabular}

Table 2. Nuclear grading (10)

\begin{tabular}{|c|c|c|c|c|c|}
\hline Nuclear grade & shape & size & chromatin & nucleoli & mitosis \\
\hline I low & uniform & $\begin{array}{l}1.5-2 \text { times the size } \\
\text { of an erythrocyte }\end{array}$ & regular & incon-spicuous & rare \\
\hline II intermediate & $\begin{array}{l}\text { moderate } \\
\text { variability }\end{array}$ & variable & coarse & $\begin{array}{l}\text { sometimes } \\
\text { prominent }\end{array}$ & maybe \\
\hline III high & $\begin{array}{l}\text { pleomorphic } \\
\text { with irregular } \\
\text { contours }\end{array}$ & $\begin{array}{c}>2.5 \text { times the size } \\
\text { of an erythrocyte }\end{array}$ & coarse & prominent & brisk \\
\hline
\end{tabular}

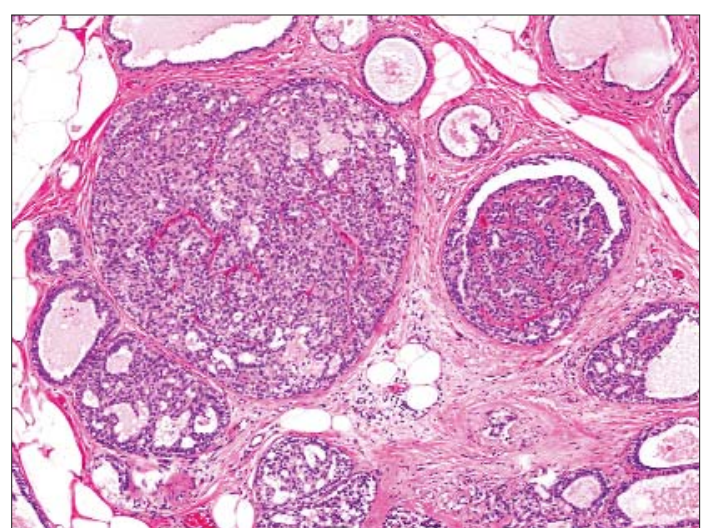

Figure 4. DCIS low grade $(\mathrm{He}, 10 \mathrm{x})$ (author's archive)

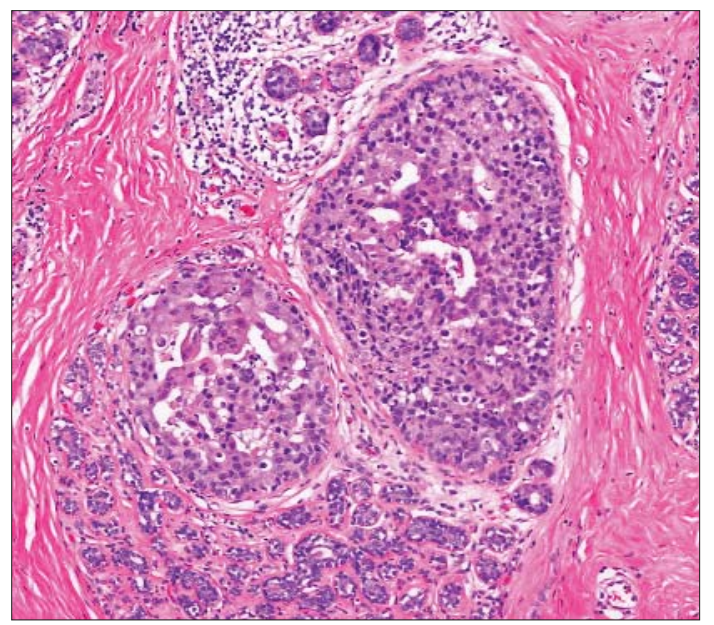

Figure 6. DCIS high grade (HE, 10x) (author's archive)

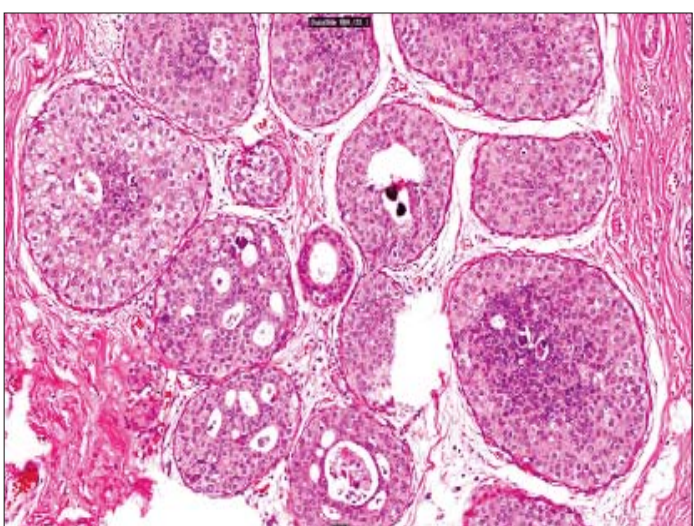

Figure 5. DCIS intermediate grade (HE, $10 \mathrm{x}$ ) (author's archive)

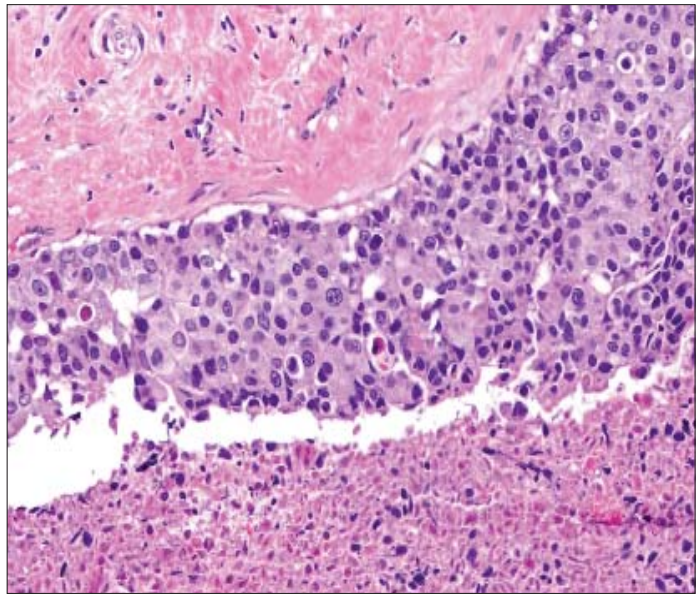

Figure 7. DCIS high grade with nuclear pleomorphism and comedo-type necrosis (HE, 20x) (author's archive) 
shaped papillae with vessels as well as an atypical epithelial overcoat within an larger epithelial-lined ductal structure. While the fine papillae lack a myoepithelial layer, it is preserved in the outer ductal structure. These account for approximately $3 \%$ of all DCIS (16). As with other DCIS, grading is based on the nuclear changes, usually a grade 1 or 2 (16).

\section{Solid papillary carcinoma in situ:}

The term "solid papillary carcinoma in situ" is used when there are solid nodules with a sharp roundish contour and are localized, regardless of whether or not a myoepithelial layer is present (17). This type of tumor has an excellent prognosis with few reported lymph node metastases (18).

\section{Paget disease}

Paget disease of the nipple shows an intraepidermal spread of atypical epithelial cells, almost always associated with a high-grade DCIS, which spreads from the subareolar ducts to the epidermis $(19,20)$.

\section{Rare subtypes}

DCIS can consist of apocrine, neuroendocrine, signet-ring or clear cells.

\section{Differential diagnosis}

The most often and challenging differential diagnosis, especially for low grade DCIS include UDH and ADH.

UDH (usual ductal hyperplasia) shows intraductal epithelial proliferation of benign and regularly distributed whorled cells. There are often slit-like lumina located in the periphery. The cells are irregularly arranged with slightly irregular nuclei. Immunohistochemistry with a high molecular weight cytokeratin reveals a mosaic-like pattern. A preserved myoepithelial layer is seen (21).

$\mathrm{ADH}$ (atypical ductal hyperplasia) is an intraductal proliferation that can be differentiated from low grade DCIS only by it's size. Both show a preserved myoepithelial layer and are similar in architecture and cell morphology. $\mathrm{ADH}$ shows micropapillary epithelial pullouts

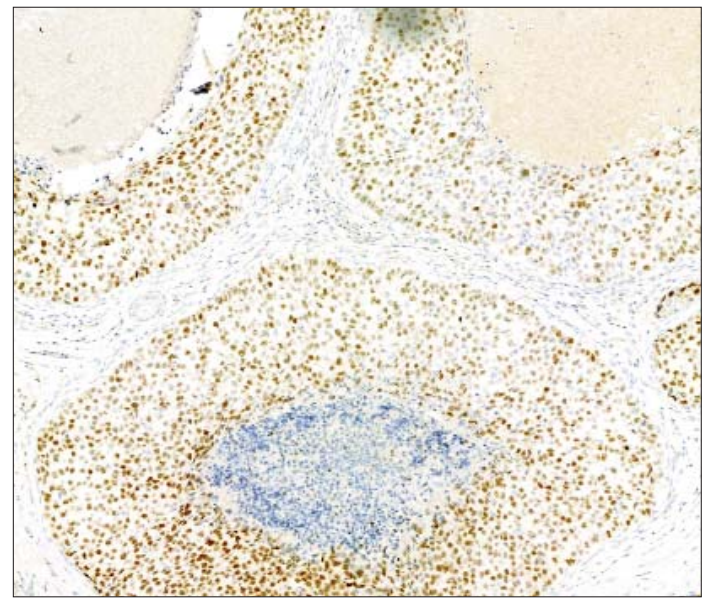

Figure 8. Estrogen receptor expression in DCIS high grade (10x) (author's archive)
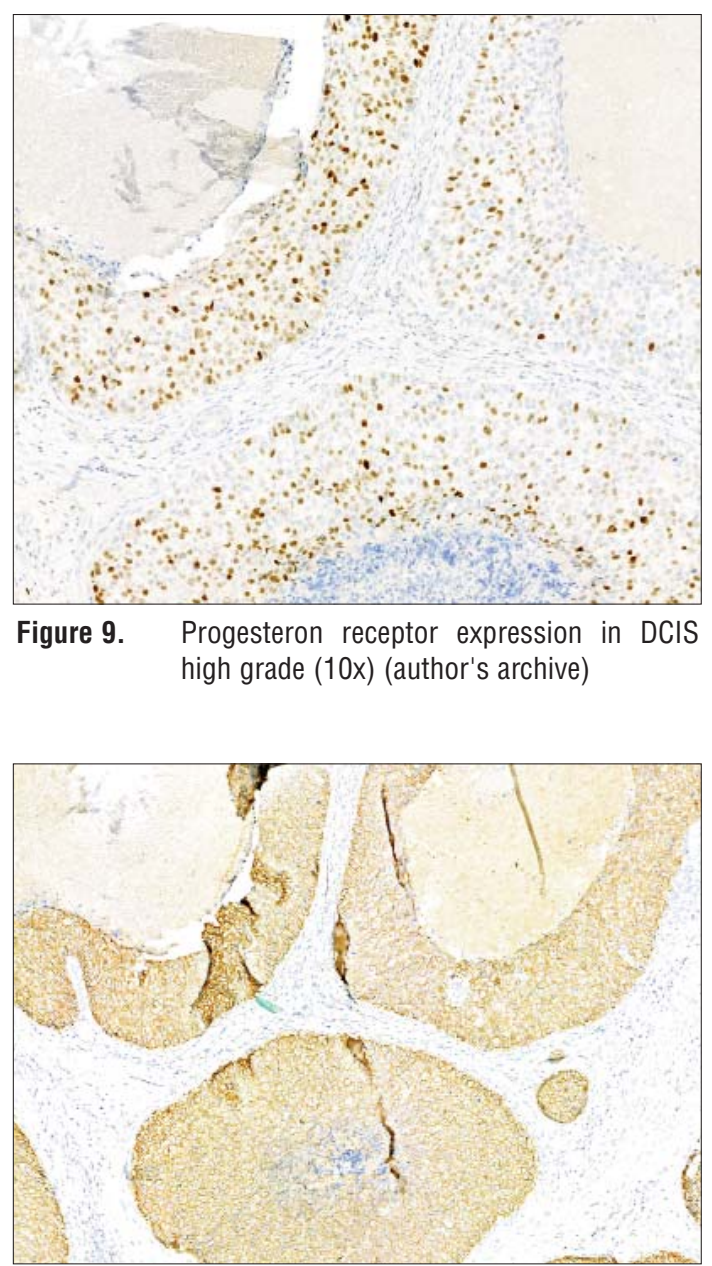

Figure 10. Her2 neu overexpression in DCIS high grade (10x) (author's archive)

or solid proliferates with round or punched out lumina. Compared to UDH the cells are 
monomorphic and proliferation is more rigid. $\mathrm{ADH}$ can be diagnosed if a maximum of two involved duct structures within less than two involved sites is present and if the lesion is less or equal $2 \mathrm{~mm}$ (only applies if ducts are completely affected) (22).

\section{Conclusions}

Although DCIS is a long known entity, on the pathology side, better predictive factors, like the nuclear gradw needs to be established to predict more safely which DCIS progresses into an invasive carcinoma in order to develop better therapy concepts.

\section{Conflict of Interest}

No conflict of interests.

\section{References}

1. Thomas J, Evans A, Macartney J, Pinder SE, Hanby A, Ellis I, et al. Sloane Project Steering Group (2010) Radiological and pathological size estimations of pure ductal carcinoma in situ of the breast, specimen handling and the influence on the success of breast conservation surgery: a review of 2564 cases from the Sloane Project. Br J Cancer. 2010;102(2):285-93.

2. Faverly DR, Burgers L, Bult P, Holland R. Three dimensional imaging of mammary ductal carcinoma in situ: clinical implications. Semin Diagn Pathol. 1994;11(3):193-8.

3. Page DL, Dupont WD, Rogers LW, Rados MS. Atypical hyperplastic lesions of the female breast. A long-term follow-up study. Cancer. 1985;55(11): 2698-708.

4. Collins LC, Tamimi RM, Baer HJ, Connolly JL, Colditz GA, Schnitt SJ Outcome of patients with ductal carcinoma in situ untreated after diagnostic biopsy: results from the Nurses' Health Study. Cancer. 2005;103(9): 1778-84.

5. Sanders ME, Schuyler PA, Simpson JF, Page DL, Dupont WD. Continued observation of the natural history of low-grade ductal carcinoma in situ reaffirms proclivity for local recurrence even after more than 30 years of follow-up. Mod Pathol. 2015;28(5):662-9. Epub 2014 Dec 12.

6. Ward BA, McKhann CF, Ravikumar TS. Ten-year follow-up of breast carcinoma in situ in Connecticut. Arch Surg. 1992;127(12):1392-5

7. Goldstein NF, Kestin L, Vicini F. Intraductal carcinoma of the breast: pathologic features associated with local recurrence in patients treated with breast-conserving therapy. Am J Surg Pathol. 2000;24(8):1058-67.

8. Lagios MD. Microinvasion of ductal carcinoma in situ. In: Silverstein MJ (ed) Ductal carcinoma in situ. Baltimore: Williams \& Wilkins. 1997; p. $241-246$

9. Kerlikowske K. Epidemiology of ductal carcinoma in situ. J Natl Cancer Inst Monogr. 2010;2010(41):139-41.

10. Lester SC, Bose S, Chen YY, Connolly JL, de Baca ME, Fitzgibbons PL, et al. Protocol for the examination of specimens from patients with invasive carcinoma of the breast. Arch Pathol Lab Med. 2009;133(10):1515-38.

11 Perry N, Broeders M, de Wolf $C$ et al (eds) (2006) European guidelines for quality assurance in breast cancer screening and diagnosis, $4^{\text {th }}$ ed, Luxembourg: Office for Official Publications of the European Communities; $h$ htps://ec.europa. eu/health/ph_projects/2002/cancer/fp_cancer_2002_ext_guid_01.pdf

12. Brierley, Gospodarowicz, Wittekind TNM Classification of Malignant Tumours. 8th Edition Oxford (UK): Wiley Blackwell; 2017.

13. Tamimi RM, Baer HJ, Marotti J, Galan M, Galaburda L, Fu Y, et al. Comparison of molecular phenotypes of ductal carcinoma in situ and invasive breast cancer. Breast Cancer Res. 2008;10(4):R67.

14. Ellsworth RE, Ellsworth DL, Love B, Patney HL, Hoffman LR, Kane J, et al. Correlation of levels and patterns of genomic instability with histological grading of DCIS. Ann Surg Oncol. 2007;14(11):3070-7.

15. Pang JM, Gorringe KL, Wong SQ, Dobrovic A, Campbell IG, Fox SB. Appraisal of the technologies and review of the genomic landscape of ductal carcinoma in situ of the breast. Breast Cancer Res. 2015;17(1):80.

16. Perez AA, Balabram D, Salles Mde A, Gobbi H. Ductal carcinoma in situ of the breast: correlation between histopathological features and age of patients. Diagn Pathol. 2014;9:227.

17. Nicolas MM, Wu Y, Middleton LP, Gilcrease MZ. Loss of myoepithelium is variable in solid papillary carcinoma of the breast. Histopathology. 2007; 51(5):657-65.

18. Guo S, Wang Y, Rohr J, Fan C, Li Q, Li X, et al. Solid papillary carcinoma of the breast: A special entity needs to be distinguished from conventional invasive carcinoma avoiding over-treatment. Breast. 2016;26:67-72.

19. Ozerdem U, McNiff JM, Tavassoli FA. Cytokeratin 7-negative mammary Paget's disease: A diagnostic pitfall. Pathol Res Pract. 2016:212(4):279-81.

20. Caliskan M, Gatti G, Sosnovskikh I, Rotmensz N, Botteri E, Musmeci S, et al. Paget's disease of the breast: the experience of the European Institute of Oncology and review of the literature. Breast Cancer Res Treat. 2008; 112(3):513-21

21. Lerwill MF. Current practical applications of diagnostic immunohistochemistry in breast pathology. Am J Surg Pathol. 2004;28(8):1076-91.

22. Moinfar F. Low-grade ductal intraepithelial neoplasia (WHO: DIN1b, Atypical Ductal Hyperplasia). In: Moinfar $F$ (ed) Essentials of Diagnostic Breast Pathology. Berlin-Heidelberg-New York-Tokyo: Springer; 2007. p 74-76. 